\title{
Vulnerability of British farms to post-Brexit subsidy removal, and implications for intensification, extensification and land sparing.
} Arnott, David; Chadwick, David; Wynne-Jones, Sophie; Jones, Davey L.

\section{Land Use Policy}

DOI:

https://doi.org/10.1016/j.landusepol.2019.104154

Published: 01/08/2021

Peer reviewed version

Cyswllt i'r cyhoeddiad / Link to publication

Dyfyniad o'r fersiwn a gyhoeddwyd / Citation for published version (APA):

Arnott, D., Chadwick, D., Wynne-Jones, S., \& Jones, D. L. (2021). Vulnerability of British farms to post-Brexit subsidy removal, and implications for intensification, extensification and land sparing. Land Use Policy, 107, [104154]. https://doi.org/10.1016/j.landusepol.2019.104154

\footnotetext{
Hawliau Cyffredinol / General rights

Copyright and moral rights for the publications made accessible in the public portal are retained by the authors and/or other copyright owners and it is a condition of accessing publications that users recognise and abide by the legal requirements associated with these rights.

- Users may download and print one copy of any publication from the public portal for the purpose of private study or research.

- You may not further distribute the material or use it for any profit-making activity or commercial gain

- You may freely distribute the URL identifying the publication in the public portal ?
}

Take down policy

If you believe that this document breaches copyright please contact us providing details, and we will remove access to the work immediately and investigate your claim. 


\title{
Vulnerability of British farms to post-Brexit subsidy removal, and implications for intensification, extensification and land sparing.
}

David Arnott ${ }^{\mathrm{a},{ }^{*}}$, David R. Chadwick ${ }^{\mathrm{a}}$, Sophie Wynne-Jones ${ }^{\mathrm{a}}$, David L. Jones ${ }^{\mathrm{a}, \mathrm{b}}$

a Environment Centre Wales, Bangor University, Bangor, Gwynedd, LL57 2UW, UK

${ }^{\mathrm{b}}$ UWA School of Agriculture and Environment, University of Western Australia, Crawley, WA 6009, Australia

*Corresponding author: E-mail address: d.arnott@bangor.ac.uk (D. Arnott)

\begin{abstract}
On the 23rd June 2016, the UK referendum on European Union (EU) membership resulted in a vote to leave the EU. This departure, should it occur, would see the implementation of a new agricultural policy within the UK which will most likely see the removal of direct financial support to farmers. In this study, we use combined agricultural survey and rural payments data to evaluate the extent of reliance upon Pillar 1 payments, based on a sample of 24,492 (i.e. $70 \%$ ) of farm holdings in Wales. This approach eliminates some of the variation found in the Farm Business Survey through the delivery of a more comprehensive picture on the numbers and types of farm holding potentially facing economic hardship and the quantities of land and livestock associated with those holdings. We estimate $\sim 34 \%$ of our sampled Welsh farm holdings face serious financial difficulties and show $\sim 4 \%$ of agricultural land on sampled farm holdings in Wales being vulnerable to land use change or abandonment. Based on our results, we consider the potential social and ecological impacts that the removal of direct payments may have on land use in Wales. We also discuss the use of a more balanced approach to land management that could support governmental visions to keep farmers on the land, improve productivity and deliver high quality 'Public Goods'.
\end{abstract}

Keywords: Brexit, land sparing, rural development, subsidy support, agricultural policy. 


\section{Introduction}

On the $23^{\text {rd }}$ June 2016, the UK referendum on European Union (EU) membership resulted in $52 \%$ of people voting to leave the EU (BBC, 2016). A departure from the EU would also see an exit from the Common Agricultural Policy's (CAP) support framework, the primary driver of UK agricultural policy for over forty years (Wallace and Scott, 2018). As a result, the UK could lose, or see to changes to, its trading relationship with the EU, be impacted by increases in trade tariffs and because of proposed changes to agriculture policy, see the reduction, and ultimate removal of the European Agricultural Fund (Pillar 1, also known as the Basic Payment Scheme (BPS); Gove, 2018; Welsh Government (WG), 2018). Independent research studies, evaluating potential impacts of an EU exit on UK agriculture, present a range of projections varying between a 'business as usual', no tariff, deal and a no EU trade agreement where the UK moves to World Trade Organisation (WTO) rules and a Most Favoured Nation (MFN) status (AHDB Horizon, 2017; Dwyer, 2018; Helm, 2017). These studies make it is clear that increased transaction costs, and the removal of Pillar 1 payments will place significant financial pressures on certain sectors of the industry and this is likely to drive change in both farming practice and land use. A proposed transition period until 2022 and potentially beyond, albeit with alterations to payment methodology, will reduce the immediate impact (Gove, 2018). However, post 2022, UK agricultural policy will significantly differ to that of the CAP, as its primary focus will be on the delivery of 'public goods for public money' through sustainable land management (Defra, 2018a; WG, 2018; WG, 2019). Whilst debate exists around the exact definition of 'public goods' (Cardwell and Smith, 2018; WG, 2018), both Gove (2018) and the Welsh Government (WG, 2018; WG, 2019) recognise the contribution farmers make to food security, rural communities and valued landscapes. Consequently, proposals for future policy-based approaches appear to promote strong multifunctionality across the agricultural spectrum through the introduction of schemes which 
aim to target social, economic, cultural and environmental capital in a bid to keep farmers on the land, increase productivity and deliver a 'green Brexit' (Gove, 2018). In Wales, the government proposes to introduce a Sustainable Land Management Scheme based on the principles of Sustainable Land Management (SLM) an internationally recognised concept, reflecting the use of land for production while ensuring long-term productive potential and maintenance of key environmental services (WG, 2019). This scheme aims to assist in making farm businesses more resilient by providing: an annual Sustainable Farming Payment to reward environmental outcomes and business support to develop the farm business. (WG, 2019). This paper evaluates the extent of reliance upon Pillar 1 payments, across UK/Welsh farms and aims to identify numbers and types of farm holding potentially facing economic hardship and the areas of land and numbers of livestock associated with those holdings. Whilst previous analysis has undertaken similar estimations based on UK Farm Business Survey data, our analysis draws on figures from government agricultural statistics and rural payment divisions to provide a more comprehensive insight.

Currently, England and each of the devolved nations, collect data on the financial, physical and environmental performance of farm businesses through June Agricultural Surveys and Farm Business Surveys (FBS). The June Agricultural Survey is the primary source for information about agricultural land, livestock and farm labour covering all known farms whilst the FBS collects detailed physical and financial information. In Wales, the annual sample for the June Agricultural Survey is c12,000 (WG, 2017a) and the annual FBS sample is c550-600 farms randomly selected from the June survey sample; WG, 2017b) for use by policy maker, researchers and farmers (Aberystwyth University, 2019). Farm business income (FBI), reported on in the FBS, is the difference between total output and total input and is the same as 
net profit. Four components of farming businesses: agricultural/standard output $(\mathrm{SO})^{1}$; the basic farm payment (BFP); agri-environment payments and diversification income e.g. renewable energy and tourism enterprises, provide the structure to FBI. Data collected on FBI enables benchmarking and the monitoring of changes to average farm income that occur over time. However, large farms receiving large Pillar 1 payments can heavily skew average incomes, concealing considerable national variation in farm level incomes (WG, 2017a). Variation in payments exists both between and within farm types (Defra, 2017a; SG, 2018; WG, 2017b) making it difficult to predict the number of farms likely to be impacted by the removal of Pillar 1 subsidies using just FBS/FBI average farm incomes. This study aims to remove some of this variation through an analysis of the CAP payments dataset (2017; Defra, 2017b) and a Welsh Statistical Office (WSO) dataset which combines June Agricultural Survey (WG, 2017a) with Rural Payments Wales (RPW) records for farms in receipt of Pillar 1 payments in 2017 (WG, 2017c). We also use the results of this study to explore the potential impacts that subsidy removal may have on land use in Wales.

\section{Methodology}

\subsection{Farm holdings and land at risk}

We identified farms most reliant on direct subsidies through an analysis of two of the four components of interest to the FBS, viz. SO and the BFP. We selected these two components as those most likely to change significantly post-Brexit. In order to identify Pillar 1 payment patterns across the UK we conducted analysis on both the 2016 and 2017 CAP payments dataset, published annually, in compliance with Regulation (EU) No 1306 (EC, 2013) and Commission Implementing Regulation (EU) No 908 (EC, 2014) (Defra, 2017b). We found no significant differences in the results for both datasets so here we present results based on the

\footnotetext{
${ }^{1}$ The standard output of an agricultural product (crop or livestock), abbreviated as SO, is the average monetary value of the agricultural output at farm-gate price. See https://ec.europa.eu/eurostat/statisticsexplained/index.php/Glossary:Standard_output (SO).
} 
2017 dataset, thereby matching the data year for the WSO dataset. Whilst the CAP payments dataset provides payment data for all countries of the UK, information combining payments data with June Agricultural Survey data was only available from the Welsh Government's Agricultural Statistics Office. We therefore used the WSO dataset to conduct a focused Waleslevel study (WG, 2017c). Farms in the WSO dataset are classified by their economic size (SO), farm type (dominant activity on a farm spilt into five categories, listed below), area of land (survey estimate excluding the use of common land), and sum of Pillar 1 payments. The farm population $(n=24,492)$ used in the WSO dataset equates to $70 \%$ of the total farm holdings in Wales ( $\mathrm{n}=35,300$; WG, 2017a) and includes all 'active' farms excluding:

- Cross border farms that are paid by Defra rather than Rural Payments Wales (RPW).

- All claimants paid by RPW that do not have a Welsh County Parish Holding (CPH) number. (Farms are required to have a CPH number if they wish to keep farm animals or apply for an agricultural subsidy).

- Any other claimants known from RPW but with no link to the Welsh Agricultural Survey i.e. holdings with little or no agricultural activity and those that specialise in pigs and/or poultry.

In this study, we focus on five farm type categories, namely:

i) Grazing livestock - Severely Disadvantaged Areas (SDA, n =7,525, 31\% of sampled population) $*^{2}$

ii) Grazing livestock - Disadvantaged Areas (DA, $\mathrm{n}=4,302,17 \%$ of sampled population)*

iii) Other grazing $(\mathrm{n}=2,448,10 \%$ of sampled population $)$

iv) Dairy $(\mathrm{n}=1,695,7 \%$ of sampled population)

\footnotetext{
$2 *$ SDA/DA land is generally suitable for extensive livestock production and for the growing of crops for feed, but agricultural production is restricted/severely restricted, by soil, relief, aspect or climate conditions (WG, 2014).
} 
v) Other farm types (Horticulture, cereals, pigs, poultry, etc., $\mathrm{n}=8,522,35 \%$ of sampled population).

A payments distribution analysis of the 2017 CAP payments dataset (Defra, 2017b) was utilised to identify Pillar 1 payment distribution patterns across the UK paying authorities. The CAP payments dataset (Defra, 2017b) provides data on the number of claimants of Pillar 1 payments, and the Agriculture in the United Kingdom 2017 report provides data on the total number of agricultural holdings per country (Defra; DAERA; Welsh Assembly Government and The Scottish Government, 2018). Difficulties arise in the accurate identification of nonclaimants in England, Scotland and Ireland, as many claimants listed in the CAP payments dataset are companies or estates claiming for more than one holding. However, in Wales, the identification of non-claimants is made more accurate using the WSO dataset and $\mathrm{CPH}$ numbers.

We conducted a cross tabulation analysis of the SO and payment brackets of the WSO dataset to provide a more detailed assessment of the number of Welsh holdings likely to be financially at risk following Pillar 1 subsidy removal. Within the WSO dataset, SO brackets are expressed in Euro $(€)$ and payments amounts in GBP $(\mathfrak{E})$. For analysis and continuity, we converted Euro $(€)$ to GBP $(\mathfrak{E})$ and in this manuscript show SO in both GBP $(\mathfrak{E})$ and Euro $(€)$. We defined farms to be potentially at financial risk following direct subsidy removal if direct payments are reasonably high in comparison to their economic size. In the category of farm holdings receiving $<£ 10 \mathrm{k}$ in direct payments, we defined all farms of a small economic size i.e. with a SO $<£ 23,400(€ 25 \mathrm{k})$ at risk as payments received can be equivalent to nearly half of the total agricultural income of the farm, suggesting a high dependency on direct payments. Given that the median payment for Welsh farmers receiving <£10k is $£ 4,171$ (Defra, 2017b) we do not include farm holdings of a higher economic size i.e. with a SO >£23,400 (€25k). The caveat to the analysis above is that, whilst it cannot be guaranteed that all farms with a SO 
$>£ 23,400$ (€25k) and a direct payment $<£ 10 \mathrm{k}$ would survive following subsidy removal they are more likely to be able to make efficiency cuts to compensate for loss of payments. In the $£ 10-20 \mathrm{k}$ and $£ 20-40 \mathrm{k}$ payment brackets, all farms of a small economic size i.e. $\mathrm{SO}<£ 23,400$ (€25 k) and some farms with a medium economic size i.e. SO £23,400 (€25 k) - £107k (€125k) are likely to be highly dependent on direct subsidies. To err on the side of caution, we included all farms with an SO of $£ 23,400$ - $£ 107 k(€ 25-125 k)$ in the estimate of farms at financial risk following subsidy removal. Farms of a high economic size i.e. SO >£107K $(€ 125 \mathrm{k})$ - £215k $(€ 250 \mathrm{k})$ and very high economic size i.e. $>£ 215 \mathrm{k}(€ 250 \mathrm{k})$ were removed as they are more likely to be able to make efficiency cuts to compensate for loss of payments. In the payment bracket $\geq £ 40 \mathrm{k}$, all farms of a small economic size i.e. those with a SO $<£ 23,400$ (€25 k) and some farms with a medium economic size i.e. SO $£ 23,400$ (€25 k) - £107K (€125k) are likely to be highly dependent on direct subsidies. Erring on the side of caution, we included all farms with an SO of $£ 23,400(€ 25 \mathrm{k})-£ 107 \mathrm{~K}(€ 125 \mathrm{k})$ in the estimate of farms at financial risk following subsidy removal. Ninety-seven farms have a high economic size i.e. SO $>£ 107 \mathrm{~K}(€ 125 \mathrm{k})$ $£ 215 \mathrm{k}(€ 250 \mathrm{k})$ and 123 have a very high economic size i.e. $\mathrm{SO}>£ 215 \mathrm{k}(€ 250 \mathrm{k})$, of these, 67 claimants receive Pillar 1 payments $>£ 100 \mathrm{k}(0.2 \%$ of total farm holdings in Wales). These are all large farms and many have very high SO and are likely to be able to reduce costs or absorb the loss of direct payments. Due to the low number of farms impacted at this level we do not include farms with a $>£ 107 \mathrm{~K}(€ 125 \mathrm{k})$ in our 'at risk' category. The number of farm in each payment brackets and associated land area identified as being potentially at risk are further categorised by farm type and results presented as a percentage of total farm type.

Whilst this study does not consider the impact of a no trade deal on farming sectors, we feel that our analysis of the WSO dataset, which combines SO and BFP through the use of CPH numbers, enables us to eliminate some of the variation surrounding average Pillar 1 payments and FBI found in the FBS. This allows us to make a more precise identification of those most 
likely to feel the impact of subsidy removal, allowing for a focused targeting of support, be it 'public goods' funding or support for sustainable production.

\subsection{Livestock held on at risk farms within Wales}

The WSO dataset contains data on stocking levels taken from the June Agricultural Survey (WG, 2017a). We used cross-tabulation to identify the total number of beef cows and sheep by payment categories and grazing farm types. We divided the total number of cows and sheep by the total number of farm holdings to provide an average livestock holding per farm holding within each category. We then multiplied the average livestock holding for both beef cows and sheep by the farm holdings identified at risk in each of the categories to give an estimated total number of beef cows and sheep held on at risk holdings.

\section{Results}

\subsection{UK Pillar 1 payment distribution}

Average income data (DAERA, 2018; Defra, 2017a; Scottish Government, 2018; Welsh Government, 2017a), across the four components of interest for farm businesses, for less favoured areas (LFA) and lowland cattle and sheep farms show average BPS and agrienvironment payments constituting a large proportion of FBI (Table 1). For example, in Wales, in the case of LFA cattle and sheep farms $>60 \%$ either make a loss or would have made a loss without subsidy (WG, 2017b). In 2017, the total number of agricultural holdings in the UK was 217,300 (DAERA; Defra; Scottish Government and the Welsh Assembly Government, 2018) and there were 143,385 claimants of Pillar 1 payments. Table 2 provides a breakdown of the total farm holdings and the total number of claimants in each of the countries of the UK. Variation exists between the countries when comparing the proportion of claimants to the total number of holdings. Some claimants in each country will be estates or companies claiming for 
more than one holding but many will be non-claimants. Farmers must have at least 5 ha of eligible land to claim BPS, and must either; produce, rear or grow agricultural products (including harvesting, milking, breeding animals and keeping animals for farming purposes) or, keep some land in a state suitable for grazing or cultivation by keeping it clear of scrub that cannot be grazed (RPA, 2018).

Payment distribution patterns for those claiming Pillar 1 subsidies are similar across all of the devolved administrations with the greatest proportion of claimants in each falling in the $£ 0$ 10k bracket (61\% N. Ireland; 46\% Scotland; 50\% Wales and 53\% England) with a UK median of $£ 3,505$ for those in this payment bracket. In fact, $39 \%$ in N. Ireland, 33\% in Scotland, 29\% in Wales and $35 \%$ in England claim $<£ 5 k$, with a UK median of $£ 2,310$ for those in this payment bracket. Detailed information linking this payment data to farm structure and income data was not available for England, Scotland and Northern Ireland, but we believe that similarities in the payment structures of the four UK countries shown in this analysis, suggests the results of our focused study of Wales will have relevance across the whole of the UK.

\subsection{Wales as a focus area to identify vulnerabilities post-subsidy removal}

The total WSO dataset population used in this focused study $(n=24,492)$ represents $70 \%$ of the total farm holdings in Wales ( $\mathrm{n}=35,300$; WG, 2017a). However, the sample farms represent $\sim 93 \%$ of the total agricultural land held on Welsh holdings in 2017 (1,686,700 ha; WG, 2017a) and $\sim 100 \%$ of the estimated sheep and $80 \%$ of the estimated beef holdings in Wales, 2017 (WG, 2017a). Therefore, we believe this sample to be indicative of what would happen across a large portion of the Welsh farming sector, and relevant to other UK countries (due to similarities in payment structures). Of the total population surveyed, 11,809(48\%) were non-claimants of Pillar 1 payments showing that, despite some estates and companies claiming 
for more than one holding, there are high levels of farm holdings with no reliance on Pillar 1 payments.

\subsection{Farm holdings assessed to be at financial risk}

We found the total holdings potentially at financial risk should direct support payments be removed and not be replaced by support mechanisms of a similar amount as being 8,328 ( 34\% of the total sampled population). We estimate 4,030 SDA (54\% of the total sampled SDA population), 2,188 DA ( $51 \%$ of the total sampled DA population), 1,059 other grazing (43\% of the total sampled other grazing population), 80 dairy (5\% of the total sampled dairy population), and 971 other farm types (11\% of the total sampled other farm type population) are potentially at risk. Table 3 gives a detailed breakdown of holdings at risk by farm type and payment bracket.

\subsection{Land area associated with at-risk holdings}

The WSO dataset (WG, 2017c) gives area of land per farm (ha) based on agricultural survey estimates (WG, 2017a) excluding the use of common land. The 1,571,593 ha of agricultural land covered by the dataset represents $93 \%$ of the total agricultural land, excluding common land, held on Welsh holdings in 2017 (1,686,700 ha; WG, 2017a). The total land is distributed between the following farm holding categories, SDA holdings (793,418 ha), DA holdings (231,465 ha), other grazing (124,327 ha), dairy (218,911 ha) and other farm holding types $(203,471)$. Using these estimates, we identified the total land held on at-risk farm holdings as 692,335 ha $\left(\sim 44 \%\right.$ of the land covered by the dataset ${ }^{3}$, table 3$)$. This equates to; $51 \%$ of the total land held on sampled SDA holdings $(407,758$ ha), $66 \%$ of land held on sampled DA holdings $(152,935 \mathrm{ha}), 60 \%$ of land held on sampled other grazing holdings

\footnotetext{
${ }^{3}$ Total percentage breakdown does not add up to $44 \%$ due to rounding up and down.
} 
(74,857 ha), $2 \%$ of land held on sampled dairy holdings (4,133 ha) and $26 \%$ of land held on sampled other farm holding types $(52,652 \mathrm{ha})$.

\subsection{Threat assessment (Beef and sheep sector)}

SDA and DA land are predominantly associated with sheep and beef grazing farms. The total number of sheep $(n=10,017,323)$ and the total number of beef cows $(n=167,500)$, covered by the WSO dataset (WG, 2017c) used in this study, equates to $\sim 100 \%$ of the estimated sheep and $80 \%$ of the estimated beef holdings in Wales, 2017 (WG, 2017a). We estimate $~ 3.4$ million sheep and $\sim 77,000$ beef cows currently graze on land deemed at risk from subsidy policy change (Table 4). This represents $34 \%$ of the total sheep flock and $46 \%$ of the beef herd covered by the dataset.

\section{Discussion}

This study estimates the potential impact of Pillar 1 subsidy removal in isolation from potential trade scenarios. Predictions made are estimates of farm holdings potentially at financial risk should Pillar 1 payments be removed and not be replaced by an alternative income source delivering similar amounts. There are some limitations to the approach and our interpretation, as it is not possible to make individual financial assessments, including off-farm and diversification income for each farm. However, the ability of the Welsh Government's Agricultural Statistics Office to create a dataset that combines farm data with rural payments has allowed this study to present a much more comprehensive 'actual' picture of business reliance across Wales than FBS averages. The June Agricultural Survey, when viewed in isolation, provides estimates for land use, livestock and labour on Welsh farms (WG, 2017a), but our use of combined datasets allows us to produce estimates of the area of land and grazing livestock associated directly with farm holdings vulnerable to change. This ability to view a 
more comprehensive picture of vulnerabilities within the agricultural landscape of Wales allows us to consider potential impacts of change. The scale and speed at which proposed change may occur means that many businesses will need to adapt quickly and change some aspect of their operations to remain viable (WG, 2018). This in turn may drive land-use change (Terres et al., 2015; van Vliet et al., 2015), viz. some farmers will consider taking on increased environmental responsibilities (Burton, 2014; Forney, 2016; WRO, 2010), some will diversify or seek other forms of income (WG, 2017b; WRO, 2010) and some will de-intensify or downsize the farm business (WRO, 2010). In contrast, some may look to intensify production to compete against a potential influx of large overseas agribusiness companies (Foote et al., 2015; Mansell, 2017). Both ends of the spectrum have been posed in debates and below we use our analysis to reflect on how extremes of intensification (expansion) or extensification (contraction) of agricultural land or practices (van Vliet et al., 2015) could impact upon land use in Wales. We also explore the use of land sparing strategies, where some land is set aside for conservation while other land is used intensively to produce agricultural commodities (Fischer et al., 2014), as an alternative to the extreme.

\subsection{Intensification}

Intensification of agricultural land primarily manifests itself as an increase in land management intensity (van Vliet et al., 2015). Technological, institutional and location factors (Latruffe et al., 2013; van Vliet et al., 2015) combined with farmer characteristics, in particular the productivist attitude of farmers (Hardaker, 2018; Hyland et al., 2016; Wynne-Jones, 2013), and the household economic conditions of the farming family (Latruffe et al., 2013; van Vliet et al., 2015) drive the intensification decision-making process. We show that $\sim 34 \%$ of sampled farmers in our dataset potentially face financial hardship following subsidy removal. These changes in economic conditions, when combined with changes to agricultural land values, may 
be a major driver of land use change. Links between land value and price support systems means changes in UK agricultural policy will likely affect land prices, resulting in both winners and losers in the sector (Roberts, 2018). In Wales, this means landowners and managers, of the $\sim 44 \%$ of sampled agricultural land we show to be on holdings potentially facing financial hardship, will have to make decisions that impact upon farm survivability. Falling land prices or agricultural product prices, combined with the loss of payments, may drive already struggling businesses to collapse (Dwyer, 2018). Whilst this may create opportunities for new entrants to the sector (Roberts, 2018) and other kinds of buyer (forestry, leisure and tourism, environmental NGOs; Dwyer, 2018) it may also encourage an influx of foreign direct investment, including investment by foreign agricultural businesses (Mansell, 2017). UK farm business consolidation may increase and become more intensive as a way to compete against large overseas agribusiness companies and this is likely to have adverse environmental impact (Baldock et al., 2017; Barnes, 2016: Foote et al., 2015). Our findings for Wales show some similarities in direct payment schemes with New Zealand, pre-subsidy removal (Federated Farmers of New Zealand, 2002), with sheep and beef farmers having a higher reliance on direct payments than other sectors. In New Zealand, immediately following subsidy removal, hill country sheep and beef farmers suffered severely, while for dairy, horticulture and cropping units the impact was generally slight (Smith and Montgomery, 2004). As a result, dairy farming intensified and expanded dramatically whilst sheep and beef sectors declined (Federated Farmers of New Zealand, 2002; Foote et al., 2015; Smith and Montgomery, 2004). With larger areas of cropland and grassland (DAERA; Defra; Scottish Government; and the Welsh Assembly Government, 2018). England may be more vulnerable to an increase in intensive practices than the other UK countries; however, in Wales levels of intensification found in New Zealand are unlikely, predominantly due to land limitations. Most of Wales is hilly or mountainous and this, combined with relatively poor soil quality and a wet climate, means the 
majority of agricultural land is restricted to the grazing of sheep and cattle (WG, 2017a). There may be opportunities for potential intensification via transfer into dairying, and an increase in beef production (Dwyer, 2018) on grazing land not in SDA's or in less marginal areas but, for grazing livestock farmers at risk in the SDA's, the availability of a new sustainable land management scheme may present the greatest opportunities to maintain viability through increased extensification.

\subsection{Extensification}

Our study shows that without intervention to support vulnerable businesses, it is likely that $\sim 34 \%$ of Welsh farmers will struggle to remain viable. Previous studies of farmers in the UK and across the EU suggests $9-20 \%$, would consider leaving farming if direct payments were to be reduced (Barnes et al., 2016; Latruffe et al., 2013; Raggi et al., 2013; WRO, 2010; 2013), but their decision to do so would be based on several factors. Natural and economic conditions surrounding the farm play a crucial role in its survival and therefore farm location will potentially force a decision to leave (Latruffe et al., 2013). Farmer age (Latruffe et al., 2013; Raggi et al. 2013) and the identification of a successor (Barnes, 2016; Lobley and Butler, 2010) also have key roles in the decision making process. In Wales, the median age of farmers is 61.2 years old (WG, 2016), only 60\% of farmers have a successor (WRO, 2010) and of those identified as most vulnerable in this study $36 \%$ are SDA and DA sheep and cattle farmers. Whilst we cannot accurately predict exit rates of Welsh farmers, we suggest that this group of farmer are most likely to consider an exit strategy, potentially releasing agricultural land to the open market (WRO, 2010; 2013; Barnes et al., 2016). In some areas, this release of land may lead to an increase in "ranching" as a way of managing land and stock, with control of the land shifting to the control of fewer farmers with larger farms (Barnes, 2016; Baldock et al, 2017; Dwyer, 2018). In other areas, this may result in destocking or land abandonment, a process 
'whereby human control over the land (e.g. agriculture, forestry) is given up and the land is left to nature' (FAO, 2006), especially in hill areas if there is little or no viable return from sheep farming (Acs et al., 2010; Terres et al., 2015; WG, 2017d). The resulting externalities can be both positive and negative (Lasanta et al., 2017; Levers et al., 2018). Whilst abandonment can occur anywhere (Terres et al., 2015), recent European studies have shown agricultural abandonment primarily occurring in less productive areas, remote and mountainous regions (van der Zanden et al., 2017). In Wales, 75\% ( 1.3 million ha) of agricultural land is categorised as disadvantaged upland habitat (SDA or DA; AHDB Horizon, 2018). We estimate ca.560,700 ha ( $43 \%$ of the total upland habitat) of land to be on SDA or DA grazing livestock holdings potentially facing financial difficulties as a direct result of Pillar 1 subsidy removal. In addition, there are $\sim 180,300$ ha of common rough grazing currently managed by SDA/DA grazing livestock farmers. This combined with the limited scope to change farming practices, make the upland habitats of Wales particularly vulnerable to abandonment.

Whilst agricultural policy change is inevitable, the potential negative social, economic and environmental impacts of abandonment must be of concern to policy-makers (Moravec and Zemeckis, 2007). Agricultural abandonment can lead to a loss of farmland biodiversity (Beilin et al., 2014; Renwick et al., 2013) and cultural landscapes (Navarro and Pereira, 2015) and drive rural redeployment (FAO, 2006), all of which have the potential to radically change upland landscapes and communities in Wales. Climate change projections which predict increased warming, droughts and drier summer conditions (EEA 2016) increase the risk of wildfires in upland habitats, especially in degraded peatland areas (Longlands and Hunter, 2018). These risks are amplified if land management practices such as agri-support (Gazzard et al., 2016) and peatland management schemes (Turetsky et al., 2015), which currently help mitigate against fire risk (Longlands and Hunter, 2018), are reduced due to land abandonment. However, there are counter arguments that highlight positive benefits associated with land 
abandonment. These include improvements to non-provisioning ecosystem services such as carbon sequestration (Munroe et al., 2013), the beneficial restoration of non-agricultural habitats (Keenleyside and Tucker, 2010), and improved soil recovery and nutrient cycling (Benayas and Bullock, 2015). There are also opportunities to reduce GHG emissions through a reduction in livestock production in Wales (because of land abandonment; MacMillan and Beeden, 2016), however there is also potential for $\mathrm{C}$ leakage, if the reduction in agriculture production is accommodated elsewhere in the UK/EU/World (Herrero, et al., 2016).

Our findings from Wales, show similar spatial patterns to Renwick et al. (2013) who found policy change mainly affecting farmers in upland habitats, which also coincide with areas of high nature value. Managing the potential multiple impacts of land use change in these upland areas will involve the use of trade-offs assessments, between socio-economic, cultural and environmental options, if strategies are to achieve multiple objectives (van der Zanden et al., 2017). Proactive land management may help mitigate against the negative externalities associated with land abandonment creating a situation where the delivery of positive Public Goods benefits can be maximised. Sustainable land management strategies must account for spatial differences between agricultural lands that may support intensification and those that underpinned by differential potential to deliver particular ecosystem services if policies are to deliver on both food security and environmental objectives. On-or-off farm diversification provides opportunities for farm business to increase viability. Previous studies (WG, 2017b; WRO, 2010) show 38-50\% of farms receiving income through diversification activities, with the Welsh FBS showing the proportion of farms with any type of diversified activity increasing each year from 2010-11, to 2016-17. In this study, we assume that there will be no decrease in diversification income and that future diversification activity will only lead to increases in farm business income. 


\subsection{Land sparing as more targeted land management strategy}

In this study, we show that abandonment is quite likely in some instances, as intensification is less likely to happen in very marginal areas, thus highlighting some of the social and ecological consequences associated with land use change. Marsden et al. (2015) also identify the need for a more cohesive and integrated approach to sustainable land management across the protected landscapes of Wales (Areas of Outstanding Natural Beauty and National Parks), if the government is to effectively resolve the more complex issues currently facing rural areas of Wales. An exit from the EU provides policy-makers, through future agricultural policy, with a unique opportunity to shape the future of the agricultural landscape using strategies that manage production, mitigate against the ecological and social risks of changing land use and ensure the survival of cultural heritage.

Governments aiming to meet increasing food demand while delivering other ecosystem goods and GHG reductions, will require farmers to produce food as sustainably possible on the most productive land available, so that more natural habitats can be "spared from the plough" (Balmford et al., 2018). Indeed, high yield farming coupled with land spared for increased carbon sequestration, could result in agricultural greenhouse gas emissions being offset by the increase in carbon stored (Lamb et al., 2016). However, others argue that the land sharing/land sparing dichotomy is too simplistic (Jiren et al., 2018) and has limited value because existing patterns of land use are more heterogeneous (Herzog and Schüepp, 2013). Loos and von Wehrden (2018) argue that given population size, and considering that few untouched natural areas remain within Europe, there is no alternative to sharing land already used by agriculture. The land sharing/land sparing debate clearly puts two important objectives on the agenda: biodiversity conservation and agricultural production (Herzog and Schüepp, 2013). These objectives are undisputable, as there is a simultaneous need to produce more food for a growing population, provide economic opportunities for those who depend on agriculture for their 
livelihoods, and reduce environmental impacts, including ecosystem degradation and high greenhouse gas emissions (Searchinger, 2014). It may be that the overarching goal of sustainably delivering social, economic, environmental and cultural objectives cannot be broken down to a single management decision such as 'sharing or sparing' and that a more balanced approach, using the principles of sparing, could provide a solution (Herzog and Schüepp, 2013). At risk, upland farmers are unlikely to be financially viable, as food producers, without some form of support (Dwyer, 2018) whilst, at risk lowland farmers have the potential, with support, to sustainably intensify production. The opportunity therefore exists to look at forms of 'sparing' within the agricultural landscape to simultaneously, increase production, deliver environmental outcomes and provide farmers with an income stream, retaining them on the land and mitigating against the social and ecological risks associated with land abandonment and intensification.

Upland farmers could receive payments to maintain cultural and spiritual ecosystem services, promoting the 'Cymru Wales' national brand (WG, 2018; WG, 2019) and working with the government to improve the condition of the protected landscapes of Wales (Marsden et al., 2015) and deliver high quality, targeted, 'public goods' at a landscape level. The collaborative spirit in the supply chain, required to increase market potential (WG, 2108a), could potentially be achieved in this area through National Park Authorities supporting farm diversification and the promotion of produce which supports brand promotion. Under these scenarios, the use of livestock as a tool to maintain habitats helps retain cultural heritage, provides additional income streams and potential access to both the sustainable farming and business support payments being offered by the proposed Welsh Government's Sustainable Farming Scheme (WG, 2019).

Access to support provided through business support payments (WG, 2019) will allow more productive 'other grazing' (i.e. not SDA/DA) and 'other farm types' to 'sustainably 
intensify', that is, increasing agricultural output while keeping the ecological footprint as small as possible (Rockström et al., 2017). These farmers, through sustainable agricultural practices in more productive landscapes, can also contribute to the sustainable 'Cymru Wales' national brand whilst providing the necessary outcomes required to deliver the government's vision to have land managers delivering both public goods and sustainable food security. Increased productivity on less land through the implementation of sustainable intensification strategies in these more productive landscapes will potentially 'spare' land to enable access to the Public Goods scheme.

\section{Conclusion}

This paper has focussed on the potential impact of Pillar 1 subsidy removal on the farming community, with a particular focus on impacts in Wales. Through access to Welsh Statistic Office and Common Agricultural Policy datasets (Defra, 2017b; WG, 2017c) we were able to identify vulnerabilities within farming communities, post-subsidy removal. Holdings in either Severely Disadvantaged Areas (SDA) or Disadvantaged Areas (DA) potentially face the highest levels of financial difficulty and are the most vulnerable to land use change. Our approach has allowed us to present a more comprehensive picture of farm holdings, land areas and livestock numbers at risk from direct subsidy removal than the averages presented in Farm Business Surveys. Based on our results we have been able to evaluate the potential social and ecological impacts that subsidy removal may have on land use in Wales. We have discussed opportunities to implement a more balanced approach to land management, based on sustainable intensification and land sparing principles that could support governmental visions (Defra, 2018a, WG, 2018; WG 2019) to keep farmers on the land, improve productivity and provide environmental benefits. 
Our findings support the Welsh Government's Sustainable Land Management approach as means to reduce risk and deliver social and ecological benefits. However, given the size of the challenge, we question whether funding levels, post-Brexit, will be sufficient to mitigate against all the social and ecological risks identified in this paper. Further research is required to measure the impact UK-wide but we would suggest that similarities in the payments structures suggests there is potential to extend this strategy across areas of England, Scotland, and Northern Ireland with similar demographics of farm typologies. This study has not addressed the subject of future trade deals with the EU and other nations and a potential move to WTO tariffs. However, an increase in transaction costs, as result of a no trade deal, is only likely to intensify the pressures on SDA/DA farmers (Dwyer, 2018) and make the possibility of a land sparing strategy more attractive.

\section{Acknowledgements}

This work was supported by the FLEXIS (Flexible Integrated Energy Systems) programme, an operation led by Cardiff University, Swansea University and the University of South Wales and funded through the Welsh European Funding Office (WEFO). We thank Stuart Neal and the Welsh Government's Agricultural Statistics Office for data provision and advice.

\section{Conflict of interest}

The authors confirm that there is no conflict of interest with the networks, organisations, and data centres referred to in the paper.

\section{References}

Aberystwyth University, 2019. Farm Business Survey. Available at:

https://www.aber.ac.uk/en/ibers/research-and-enterprise/fbs/ (accessed 26.02.19). 
Acs, S., Hanley, N., Dallimer, M., Gaston, K.J., Robertson, P., Wilson, P., Armsworth, P.R., 2010. The effect of decoupling on marginal agricultural systems: Implications for farm incomes, land use and upland ecology. Land Use Policy 27, 550-563.

https://doi.org/10.1016/j.landusepol.2009.07.009.

AHDB Horizon, 2017. Brexit Scenarios: an impact assessment, AHDB Market Intelligence. Available at: https://www.nfuonline.com/horizon_brexitscenarios_2017-10-10/ (accessed 04.10.18).

AHDB Horizon, 2018. Exploring the implications of Brexit for agriculture and horticulture in Wales. AHDB. Warwickshire.

Baldock D, Buckwell A, Hart K and Maréchal A. 2017. EU referendum and implications for UK agriculture and the environment, report produced for the UK Land Use Policy Group, IEEP London.

Balmford, A., Amano, T., Bartlett, H., Chadwick, D., Collins, A., Edwards, D., Field, R., Garnsworthy, P., Green, R., Smith, P., Waters, H., Whitmore, A., Broom, D. Chara, J., Finch, T., Garnett, E., Gathorne-Hardy, A., Hernandez-Medrano, J., Herrero, M., Hua, F., Latawiec, A., Misselbrook, T., Phalan, B., Simmons, B., Takahashi, T., Vause, J., zu Ermgassen, E., Eisner, R. 2018. The environmental costs and benefits of high-yield farming. Nature Sustainability 1(9), p.477.

Barnes, A., Sutherland, L.-A., Toma, L., Matthews, K., Thomson, S., 2016. The effect of the Common Agricultural Policy reforms on intentions towards food production: Evidence from livestock farmers. Land Use Policy 50, 548-558. https://doi.org/10.1016/j.landusepol.2015.10.017. BBC, 2016. EU Referendum: Results. Available at: http://www.bbc.co.uk/news/politics/eu_referendum/results. (accessed 04.10.18). 
Beilin, R., Lindborg, R., Stenseke, M., Pereira, H.M., Llausàs, A., Slätmo, E., Cerqueira, Y., Navarro, L., Rodrigues, P., Reichelt, N., Munro, N., Queiroz, C., 2014. Analysing how drivers of agricultural land abandonment affect biodiversity and cultural landscapes using case studies from Scandinavia, Iberia and Oceania. Land Use Policy 36, 60-72. https://doi.org/10.1016/j.landusepol.2013.07.003.

Benayas, J.M.R., Bullock, J.M., 2015. Vegetation restoration and other actions to enhance wildlife in European agricultural landscapes, Rewilding European Landscapes. https://doi.org/10.1007/978-3-319-12039-3_7.

Burton, R.J., 2014. The influence of farmer demographic characteristics on environmental behaviour: A review. Journal of environmental management, 135, pp.19-26.

Cardwell, M. and Smith, F., 2018. Charting a New Course for the United Kingdom AgriFood Sector-Health and Harmony: The Future for Food, Farming and the Environment in a Green Brexit. The Political Quarterly. https://doi.org/10.1111/1467-923X.12515

DAERA, 2018. Farm Incomes in Northern Ireland 2016/17. Available at: https://www.daerani.gov.uk/sites/default/files/publications/daera/Farm\%20Incomes\%20in\%20Northern\%20Irel and\%20for\%202016-17.pdf (accessed 04.10.18).

Defra, 2017a. Farm Business Income by type of farm in England, 2016/17. Available at: https://assets.publishing.service.gov.uk/government/uploads/system/uploads/attachment_data /file/655060/fbs-businessincome-statsnotice-26oct17.pdf (accessed 04.10.18).

Defra, 2017b. [Dataset] CAP Payments Data (2017). Available at: http://www.cappayments.defra.gov.uk/download.aspx (accessed 04.10.18).

Department for Environment, Food and Rural Affairs; Department of Agriculture, Environment and Rural Affairs (Northern Ireland); Welsh Assembly Government, The Department for Rural Affairs and Heritage and The Scottish Government, Rural and 
Environment Science and Analytical Services. 2018. Agriculture in the U.K. 2017. Available at:

https://assets.publishing.service.gov.uk/government/uploads/system/uploads/attachment_data /file/741062/AUK-2017-18sep18.pdf (accessed 27.02.18).

Defra, 2018a. Health and Harmony: The future for food, farming and the environment in a green Brexit. Available at:

https://assets.publishing.service.gov.uk/government/uploads/system/uploads/attachment_data /file/684003/future-farming-environment-consult-document.pdf (accessed 04.10.18)

Defra, 2018b. The future farming and environment evidence compendium. Available at: https://assets.publishing.service.gov.uk/government/uploads/system/uploads/attachment_data /file/683972/future-farming-environment-evidence.pdf.

Devlin, S. and Wheatley, H., 2017. Agricultural subsidies in the UK after Brexit: A progressive solution. Available at:

https://www.globaljustice.org.uk/sites/default/files/files/resources/postbrexitagsubsidies_repo rt_web_1.pdf (accessed 04.10.18).

Dwyer, J., 2018. The Implications of Brexit for Agriculture , Rural Areas and Land Use in Wales. Available at: https://www.wcpp.org.uk/wp-content/uploads/2018/04/TheImplications-of-Brexit-for-Agriculture-Rural-Areas-and-Land-Use-in-Wales-1.pdf (accessed 04.10.18).

European Environment Agency [EEA] (2016) How is climate change affecting forest fire risk in Europe? Available at: https://www.eea.europa.eu/data-and-maps/indicators/forest-firedanger-2/ assessment (Accessed 27.03.19).European Commission, 2013. Regulation (EU) No 1306/2013 of the European Parliament and of the Council of 17 December 2013 on the 
financing, management and monitoring of the common agricultural policy and repealing Council Regulations (EEC) No 352/78, (EC) No 165/94, (EC) No 2799/98 549-607.

European Commission, 2014. Commission Implementing Regulation (EU) No 908/2014 b of 6 August 2014 laying down rules for the application of Regulation (EU) No 1306/2013 of the European Parliament and of the Council with regard to paying agencies and other bodies, financial management 2014.

Evans-Pritchard, A., 2015. Brexit is a life or death matter for Britain's farmers. The Telegraph. Available at: https://www.telegraph.co.uk/finance/economics/11967049/Brexit-isa-life-or-death-matter-for-Britains-farmers.html (accessed 04.10.18).

FAO, 2006. The Role of Agriculture and Rural Development in Revitalizing Abandoned/Depopulated Areas. Food and Agriculture Organization of the United Nations, Rome. Available at:

https://pdfs.semanticscholar.org/8795/e3b5fb039efa5cf7fafa41735c694c572f75.pdf?_ga=2.1 $\underline{52026171.309400197 .1538733740-2099244240.1538733740}$ (accessed 04.10.18).

Federated Farmers of New Zealand, 2002. Life After Subsidies (3rd ed.). Federated Farmers, Wellington.

Fischer, J., Abson, D.J., Butsic, V., Chappell, M.J., Ekroos, J., Hanspach, J., Kuemmerle, T., Smith, H.G. and von Wehrden, H., 2014. Land sparing versus land sharing: moving forward. Conservation Letters, 7(3), pp.149-157.

Foote, K.J., Joy, M.K., Death, R.G., 2015. New Zealand Dairy Farming: Milking Our Environment for All Its Worth. Environ. Manage. 56, 709-720.

https://doi.org/10.1007/s00267-015-0517-x. 
Forney, J., 2016. Blind spots in agri-environmental governance: some reflections and suggestions from Switzerland. Review of Agricultural, Food and Environmental Studies, 97(1), pp.1-13.

Gazzard, R., McMorrow, J. and Aylen, J., 2016. Wildfire policy and management in England: an evolving response from Fire and Rescue Services, forestry and cross-sector groups. Philosophical Transactions of the Royal Society B: Biological Sciences, 371(1696), p.20150341.

Gove, M., 2018. Farming for the next generation. Speech to the Oxford Farming Conference 2018. Available at: https://www.gov.uk/government/speeches/farming-for-the-nextgeneration. (accessed 04.10.18).

Hardaker, A., 2018. Is forestry really more profitable than upland farming? A historic and present day farm level economic comparison of upland sheep farming and forestry in the UK. Land Use Policy 71, 98-120. https://doi.org/10.1016/j.landusepol.2017.11.032.

Helm, D., 2017. Agriculture after Brexit. Oxford Review of Economic Policy, 33(suppl_1), pp. S124-S133.

Herrero, M., Henderson, B., Havlík, P., Thornton, P.K., Conant, R.T., Smith, P., Wirsenius, S., Hristov, A.N., Gerber, P., Gill, M. and Butterbach-Bahl, K., 2016. Greenhouse gas mitigation potentials in the livestock sector. Nature Climate Change, 6(5), p.452.

Herzog, F. and Schüepp, C., 2013. Are land sparing and land sharing real alternatives for European agricultural landscapes. Aspects of Applied Biology, 121, pp.109-116.

Hyland, J.J., Jones, D.L., Parkhill, K.A., Barnes, A.P. and Williams, A.P., 2016. Farmers' perceptions of climate change: identifying types. Agriculture and Human Values, 33(2), pp.323-339. 
Jiren, T.S., Dorresteijn, I., Schultner, J. and Fischer, J., 2018. The governance of land use strategies: Institutional and social dimensions of land sparing and land sharing. Conservation Letters, 11(3), p.e12429.

Keenleyside, C., Tucker, G.M., 2010. Farmland abandonment in the EU: an assessment of trends and prospects. Report prepared for WWF. London: Institute for European Environmental Policy (IEEP).

Lamb, A., Green, R., Bateman, I., Broadmeadow, M., Bruce, T., Burney, J., Carey, P., Chadwick, D., Crane, E., Field, R., Goulding, K., Griffiths, H., Hastings, A., Kasoar, T., Kindred, D., Phalan, B., Pickett, J., Smith, P., Wall, E., zu Ermgassen, E.K.H.J., Balmford, A. 2016. Land sparing as a mechanism to offset greenhouse gas emissions from agriculture. Nature Climate Change 6(5), 488-492.

Lasanta, T., Arnáez, J., Pascual, N., Ruiz-Flaño, P., Errea, M.P., Lana-Renault, N., 2017. Space-time process and drivers of land abandonment in Europe. Catena 149, 810-823. https://doi.org/10.1016/j.catena.2016.02.024.

Latruffe, L., Dupuy, A. and Desjeux, Y., 2013. What would farmers' strategies be in a noCAP situation? An illustration from two regions in France. Journal of Rural Studies, 32, pp.10-25.

Levers, C., Schneider, M., Prishchepov, A.V., Estel, S. and Kuemmerle, T., 2018. Spatial variation in determinants of agricultural land abandonment in Europe. Science of the Total Environment, 644, pp.95-111.

Lobley, M. and Butler, A., 2010. The impact of CAP reform on farmers' plans for the future: Some evidence from South West England. Food Policy, 35(4), pp.341-348.

Longlands, S. and Hunter, J. 2018. Natural Assets North: Valuing Our Uplands. Institute for Public Policy Research (North). Manchester. 
Loos, J. and von Wehrden, H., 2018. Beyond Biodiversity Conservation: Land Sharing Constitutes Sustainable Agriculture in European Cultural Landscapes. Sustainability, 10(5), p. 1395.

MacMillan, A. and Beeden, P., 2016. The UK should seize the Brexit moment to reform its food policies (and become a role model for other countries). Agriculture Development, p.18.

Mansell, K. 2017. Inquiry into Trade Post-Brexit. All Party Parliamentary Group on Agroecology for Sustainable Food and Farming. Available at: https://agroecologyappg.org/wp-content/uploads/2018/01/APPG-on-Agroecology-Inquiry-into-Trade-PostBrexit-2.pdf (accessed 30.07.18).

Marsden, T., Lloyd-Jones, J. and Williams, R., 2015. National Landscapes: Realising their Potential. The Review of Designated Landscapes in Wales. Available at: https://gov.wales/docs/desh/publications/151020-review-designated-landscapes-report-en.pdf (accessed 05.01.19).

Moravec, J. and Zemeckis, R., 2007 Cross Compliance and Land Abandonment: A Research Paper of the Cross Compliance Network; Contract of the European Community's Sixth Framework Programme. SSPE-CT-2005-022727.

Munroe, D.K., van Berkel, D.B., Verburg, P.H. and Olson, J.L., 2013. Alternative trajectories of land abandonment: causes, consequences and research challenges. Current Opinion in Environmental Sustainability, 5(5), pp.471-476.

Navarro, L. M., \& Pereira, H.M., 2015. Rewilding abandoned landscapes in Europe. Rewilding Eur. Landscapes (pp. 3-23). Springer, Cham.

Raggi, M., Sardonini, L. and Viaggi, D., 2013. The effects of the Common Agricultural Policy on exit strategies and land re-allocation. Land Use Policy, 31, pp.114-125. 
Renwick, A., Jansson, T., Verburg, P.H., Revoredo-Giha, C., Britz, W., Gocht, A., McCracken, D., 2013. Policy reform and agricultural land abandonment in the EU. Land Use Policy 30, 446-457. https://doi.org/10.1016/j.landusepol.2012.04.005.

Roberts, D. 2018. How will Brexit affect UK agricultural land values (and why does it matter)? The James Hutton Institute. Available at: https://www.hutton.ac.uk/blogs/how-willbrexit-affect-uk-agricultural-land-values-and-why-does-it-matter (accessed 05.01.19).

Rockström, J., Williams, J., Daily, G., Noble, A., Matthews, N., Gordon, L., Wetterstrand, H., DeClerck, F., Shah, M., Steduto, P. and de Fraiture, C., 2017. Sustainable intensification of agriculture for human prosperity and global sustainability. Ambio, 46(1), pp.4-17.

Rural Payments Agency, 2018. Basic Payment Scheme: rules for 2018. Available at: https://assets.publishing.service.gov.uk/government/uploads/system/uploads/attachment_data /file/705756/BPS_2018_scheme_rules_v5.0.pdf (accessed 27.02.19).

Scottish Government, 2018. Annual Estimates of Scottish Farm Business Income (FBI). 2016/17 1-52. https://doi.org/978-1-78851-674-7.

Searchinger, T., Hanson, C., Ranganathan, J., Lipinski, B., Waite, R., Winterbottom, R., Dinshaw, A., Heimlich, R., Boval, M., Chemineau, P. and Dumas, P., 2014. Creating a sustainable food future. A menu of solutions to sustainably feed more than 9 billion people by 2050. World resources report 2013-14: interim findings.

Smith, W., Montgomery, H., 2004. Revolution or evolution? New Zealand agriculture since 1984. GeoJournal 59, 107-118. https://doi.org/10.1023/B:GEJO.0000019969.38496.82.

Swinbank, A., 2017. World Trade Rules and the Policy Options for British Agriculture PostBrexit. Available at: http://blogs.sussex.ac.uk/uktpo/files/2017/01/Briefing-paper-7.pdf (accessed 04.10.18). 
Terres, J.M., Scacchiafichi, L.N., Wania, A., Ambar, M., Anguiano, E., Buckwell, A., Coppola, A., Gocht, A., Källström, H.N., Pointereau, P., Strijker, D., Visek, L., Vranken, L., Zobena, A., 2015. Farmland abandonment in Europe: Identification of drivers and indicators, and development of a composite indicator of risk. Land Use Policy 49, 20-34. https://doi.org/10.1016/j.landusepol.2015.06.009.

Turetsky, M.R., Benscoter, B., Page, S., Rein, G., Van der Werf, G.R. and Watts, A., 2015. Global vulnerability of peatlands to fire and carbon loss. Nature Geoscience, 8(1), p.11. van der Zanden, E.H., Verburg, P.H., Schulp, C.J.E., Verkerk, P.J., 2017. Trade-offs of European agricultural abandonment. Land Use Policy 62, 290-301. https://doi.org/10.1016/j.landusepol.2017.01.003.

van Vliet, J., de Groot, H.L.F., Rietveld, P., Verburg, P.H., 2015. Manifestations and underlying drivers of agricultural land use change in Europe. Landsc. Urban Plan. 133, 2436. https://doi.org/10.1016/j.landurbplan.2014.09.001.

Wales Rural Observatory, 2010. Wales Rural Observatory: A Survey of Farming Households in Wales, July 2010. Available at:

http://www.walesruralobservatory.org.uk/sites/default/files/SurveyFarmingHouseholdsWales 2010_0.pdf (accessed 15.10.18).

Wales Rural Observatory, 2013. Wales Rural Observatory: Rural Household Survey 2013. Available at: http://www.walesruralobservatory.org.uk/sites/default/files/Rural\%20Household\%20Survey \%202013.pdf (accessed 15.03.19).

Wallace, M. and Scott, C., 2018. Impact of Brexit Scenarios on Grazing Livestock Farms in the Lake District National Park. 
Welsh Government, 2014. Welsh Statutory Instruments (2014) No. 1835 (W. 189)

Agriculture, Wales. The Common Agricultural Policy Basic Payment Scheme (Provisional Payment Region Classification) (Wales) Regulations 2014.

Welsh Government, 2016. Welsh Agricultural Statistics 2016. Available at:

https://gov.wales/sites/default/files/statistics-and-research/2018-12/180130-welsh-

agricultural-statistics-2016-ency.pdf (accessed 21.03.19).

Welsh Government, 2017a. June 2017 Survey of Agriculture and Horticulture: Results for Wales. https://doi.org/10.0

Welsh Government, 2017b. Farm incomes in Wales, 2016-17. Available at: https://gov.wales/docs/statistics/2017/171213-farm-incomes-2016-17-en.pdf (accessed 04.10.18).

Welsh Government, 2017c. [Dataset] Summary of June Survey and Payments information for Wales for 2017. Welsh Statistics Office. Cardiff.

Welsh Government, 2017d. Summary of EU Exit Scenario Planning Workshops. Available at: https://gov.wales/docs/drah/publications/180219-summary-of-eu-exit-scenario-planningworkshops-en.pdf (accessed 04.10.18).

Welsh Government, 2018. Brexit and our land: Securing the future of Welsh farming. Available at: https://beta.gov.wales/sites/default/files/consultations/2018-07/brexit-and-ourland-consultation-document_0.pdf (accessed 04.10.18).

Welsh Government, 2019. Sustainable Farming and our Land. Available at: https://gov.wales/sites/default/files/consultations/2019-07/brexit-consultation-document.pdf (accessed 30.07.19). 
Wynne-Jones, S., 2013. Ecosystem Service Delivery in Wales: Evaluating Farmers'

Engagement and Willingness to Participate. J. Environ. Policy Plan. 15, 493-511. https://doi.org/10.1080/1523908X.2013.788443. 
Table 1. Summary of farm business statistics for cattle and sheep farms in less favoured areas (LFA) and Lowland areas across UK for the 2016-17 accounting year. Source: (Defra, 2017a; Welsh Government, 2017a; DAERA, 2018; Scottish Government, 2018).

\begin{tabular}{|c|c|c|c|c|c|c|c|c|}
\hline \multirow[t]{3}{*}{ Income by cost centres } & \multirow{2}{*}{\multicolumn{4}{|c|}{$\begin{array}{l}\text { Cattle and sheep (LFA) } \\
\text { Average per farm (f) }\end{array}$}} & \multirow{2}{*}{\multicolumn{4}{|c|}{$\begin{array}{c}\text { Cattle and sheep (lowland) } \\
\text { Average per farm (f) }\end{array}$}} \\
\hline & & & & & & & & \\
\hline & England & Scotland & Wales & N. Ireland & England & Scotland & Wales & N. Ireland \\
\hline Agriculture & $-9,400$ & $-24,409$ & $-6,200$ & $-10,674$ & $-8,700$ & $-19,376$ & 4,100 & $-7,847$ \\
\hline Basic / single farm payment & 22,800 & 40,867 & 21,000 & 32,027 & 15,300 & 31,905 & 14,100 & 24,424 \\
\hline Agri-environment & 11,200 & 13,825 & 5,600 & & 3,000 & 2,360 & 1,600 & \\
\hline Diversification/contracting & 2,400 & 13,825 & 2,700 & & 6,500 & 3,363 & 3,000 & \\
\hline Total farm business income & 27,000 & 35,284 & 23,100 & 21,352 & 16,100 & 18,253 & 22,700 & 16,578 \\
\hline
\end{tabular}

Table 2. The total number of farm holdings and claimants of Pillar 1 payments by Country of paying authority. Source: (Defra, 2017b; Defra; DAERA (Northern Ireland); Welsh Government, and the Scottish Government. 2018)

\begin{tabular}{lcc}
\hline Country & Number of holdings & Number of claimants \\
\hline England & 106000 & 85734 \\
Scotland & 51000 & 17990 \\
Wales & 35300 & 15431 \\
Northern Ireland & 25000 & 24230 \\
\hline Total & 217300 & 143385 \\
\hline
\end{tabular}


2 Severely Disadvantaged Areas (SDA) grazing; Disadvantaged Areas (DA) grazing; other grazing; dairy and other farm types. (SDA and DA definitions, WG, 2014).

\begin{tabular}{|c|c|c|c|c|c|c|c|c|c|c|c|}
\hline Farm type & SDA grazing & & DA grazing & & Other grazing & & Dairy & & Others & & \\
\hline Payment bracket & $\begin{array}{c}\text { No of } \\
\text { claimants }\end{array}$ & $\begin{array}{c}\text { Land } \\
\text { area (ha) }\end{array}$ & $\begin{array}{c}\text { No of } \\
\text { claimants }\end{array}$ & $\begin{array}{c}\text { Land } \\
\text { area (ha) }\end{array}$ & $\begin{array}{c}\text { No of } \\
\text { claimants }\end{array}$ & $\begin{array}{c}\text { Land } \\
\text { area (ha) }\end{array}$ & $\begin{array}{c}\text { No of } \\
\text { claimants }\end{array}$ & $\begin{array}{c}\text { Land } \\
\text { area (ha) }\end{array}$ & $\begin{array}{c}\text { No of } \\
\text { claimants }\end{array}$ & $\begin{array}{l}\text { Land } \\
\text { area (ha) }\end{array}$ & Totals \\
\hline Under f10k & 1,239 & 27,189 & 1,090 & 24,701 & 511 & 11,490 & 25 & 458 & 602 & 14,137 & \\
\hline f10-20k & 1,437 & 152,188 & 788 & 81,515 & 415 & 42,156 & 53 & 3,598 & 282 & 26,202 & \\
\hline f20-40k & 1,027 & 173,563 & 273 & 41,648 & 122 & 19,718 & 2 & 77 & 67 & 9,776 & \\
\hline$\geq f 40 k$ & 327 & 54,818 & 37 & 5,071 & 11 & 1,493 & 0 & 0 & 20 & 2,537 & \\
\hline $\begin{array}{l}\text { Total number of } \\
\text { holdings at risk }\end{array}$ & 4,030 & & 2,188 & & 1,059 & & 80 & & 971 & & 8,328 \\
\hline $\begin{array}{l}\text { Total land area at } \\
\text { risk of change (ha) }\end{array}$ & & 407,758 & & 152,935 & & 74,857 & & 4,133 & & 52,652 & 692,335 \\
\hline
\end{tabular}

3 


\begin{tabular}{|c|c|c|c|c|c|c|c|c|c|c|}
\hline Farm type & SDA grazing & & & DA grazing & & & Dther grazing & & & \\
\hline Payment bracket & $\begin{array}{c}\text { No of } \\
\text { Claimants }\end{array}$ & $\begin{array}{c}\text { Total beef } \\
\text { cows }\end{array}$ & Total sheep & $\begin{array}{c}\text { No of } \\
\text { claimants }\end{array}$ & $\begin{array}{c}\text { Total beef } \\
\text { cows }\end{array}$ & Total sheep & $\begin{array}{c}\text { No of } \\
\text { claimants }\end{array}$ & $\begin{array}{c}\text { Total beef } \\
\text { cows }\end{array}$ & Total sheep & Totals \\
\hline Under $f 10 k$ & 1,239 & 2,610 & 156,399 & 1,090 & 4,269 & 27,279 & 511 & 1,860 & 14,186 & \\
\hline f10-20k & 1,437 & 13,408 & 986,271 & 788 & 13,247 & 343,626 & 415 & 6,311 & 143,774 & \\
\hline f20-40k & 1,027 & 16,945 & $1,086,983$ & 273 & 7,344 & 183,412 & 122 & 3,334 & 51,344 & \\
\hline$\geq € 40 k$ & 327 & 6,199 & 350,468 & 37 & 1,060 & 21,393 & 11 & 77 & 9,319 & \\
\hline Total claimants & 4,030 & & & 2,188 & & & 1,059 & & & 7,277 \\
\hline Total beef cattle & & 39,161 & & & 25,920 & & & 11,582 & & 76,663 \\
\hline Total sheep & & & $2,580,120$ & & & 575,710 & & & 218,623 & $3,374,453$ \\
\hline
\end{tabular}

7 


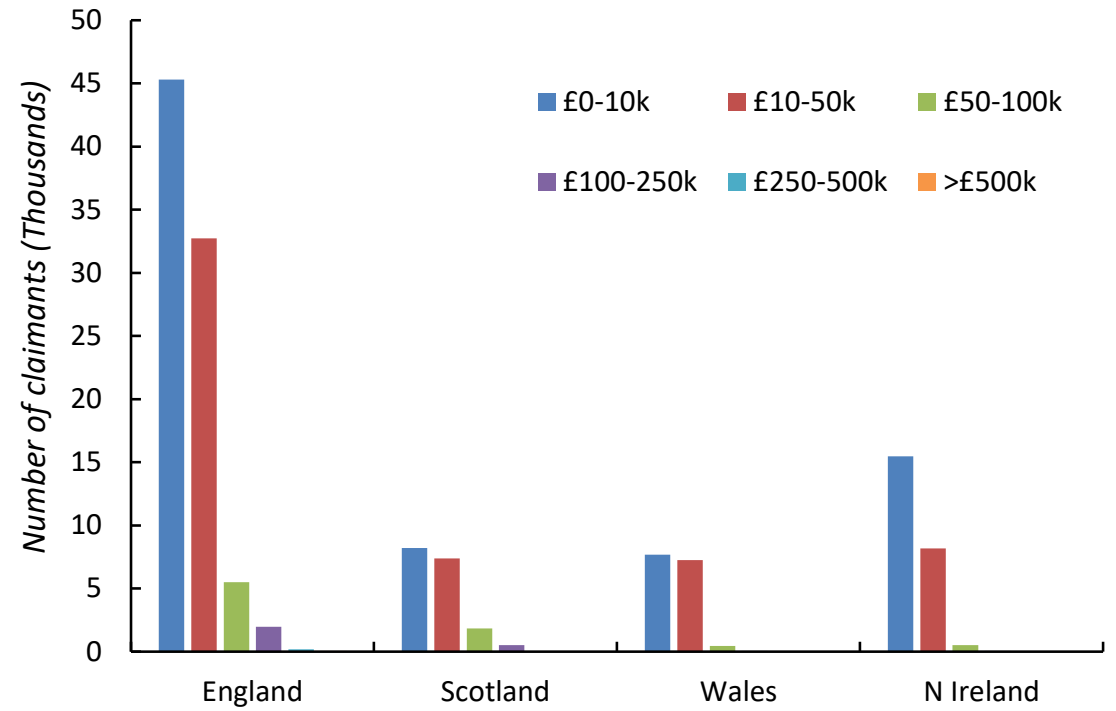

12 Figure 1. Pillar 1 (basic Payment Scheme + greening payment) claimants for 2017 by payment agency country of 13 origin and payment bracket. Source: (Defra, 2017b). 